\title{
Clinical management of transsexual subjects
}

\author{
Manejo clínico de sujeitos transexuais
}

Elaine Maria Frade Costa', Berenice Bilharinho Mendonca ${ }^{2}$

\begin{abstract}
' Disciplina de Endocrinologia, Faculdade de Medicina da Universidade de São Paulo (FMUSP). Serviço de Endocrinologia e Metabologia, Hospital das Clínicas (HC), FMUSP. Ambulatório de Transexualismo, HCFMUSP. Comitê Técnico do Ministério da Saúde para Regulamentação do Processo Transexualizador no Sistema Único de Saúde (SUS), São Paulo, SP, Brazil ${ }_{2}^{2}$ Disciplina de Endocrinologia e Metabologia, FMUSP, São Paulo, SP, Brazil
\end{abstract}

\begin{abstract}
Transsexual subjects are individuals who have a desire to live and be accepted as a member of the opposite sex, usually accompanied by a sense of discomfort with, or inappropriateness of, one's anatomic sex, and a wish to have surgery and hormonal treatment to make one's body as congruent as possible with one's preferred sex. They seek to develop the physical characteristics of the desired gender, and should undergo an effective and safe treatment regimen. The goal of treatment is to rehabilitate the individual as a member of society in the gender he or she identifies with. Sex reassignment procedures necessary for the treatment of transsexual patients are allowed in our country, at Medical Services that have a multidisciplinary team composed of a psychologist, a social worker, a psychiatrist, an endocrinologist and surgeons (gynecologists, plastic surgeons, and urologists). Patients must be between 21 to 75 years old and in psychological and hormonal treatment for at least 2 years. Testosterone is the principal agent used to induce male characteristics in female transsexual patients, and the estrogen is the chosen hormone used to induce the female sexual characteristics in male transsexual patients. Based on our 15 years of experience, we can conclude that testosterone and estradiol treatment in physiological doses are effective and safe in female and male transsexual patients, respectively. Arq Bras Endocrinol Metab. 2014;58(2):188-96
\end{abstract}

Keywords

Transsexualism; hormone treatment; management

\section{RESUMO}

Transexualismo masculino refere-se ao indivíduo 46,XY com fenótipo masculino normal que deseja viver e ser aceito como membro do sexo feminino, já o transexualismo feminino refere-se ao indivíduo 46,XX com fenótipo feminino normal que deseja viver e ser aceito como membro do sexo masculino. Há 16 anos os procedimentos médicos clínicos e cirúrgicos necessários para o tratamento de pacientes transexuais estão autorizados e regulamentados no nosso país, desde que os Serviços onde forem realizados tais procedimentos contem com equipe multidisciplinar composta por psicólogo, assistente social, psiquiatra, endocrinologista e cirurgiões (ginecologistas, plásticos e urologistas). Para serem submetidos à cirurgia, os pacientes devem ter de 21 a 75 anos, devem ter realizado hormonioterapia por pelo menos um ano e psicoterapia por pelo menos dois anos. Os indivíduos transexuais buscam desenvolver características físicas pertencentes ao sexo desejado e devem ser submetidos a um regime de tratamento efetivo e seguro com o objetivo de reabilitá-los como membros da sociedade no gênero com o qual eles se identificam. A testosterona é o principal hormônio utilizado para induzir o desenvolvimento dos caracteres sexuais secundários masculinos nos transexuais femininos e o estrógeno é o hormônio utilizado para induzir os caracteres sexuais secundários femininos no transexual masculino. Com base na experiência do nosso serviço, podemos afirmar que doses fisiológicas desses hormônios são capazes de produzir os efeitos desejados sem causar efeitos colaterais importantes. Arq Bras Endocrinol Metab. 2014;58(2):188-96

\section{Descritores}

Transexualismo; tratamento hormonal; manejo

\section{INTRODUCTION}

T ndividuals whose gender assigned at birth is contrary to the one they identify themselves with are differ3 ently named according to the source: the International
Classification of Diseases - version 10 (ICD-10), the Diagnostic and Statistical Manual of Mental Disorders in version 4 (DSM-4), or the recently published, DSM - version 5 . 
According to ICD-10, this condition is called Transsexualism (F64.0), defined as: " $A$ desire to live and be accepted as a member of the opposite sex, usually accompanied by a sense of discomfort with, or inappropriateness of, one's anatomic sex, and a wish to have surgery and hormonal treatment to make one's body as congruent as possible with one's preferred sex (1)".

Gender Identity Disorder, denomination given by the (DSM-4), is attributed to individuals who manifest marked uneasiness with the desire to live and be accepted as a member of the opposite sex. This concern may be manifested as an intense desire to adopt the social role of the opposite sex or to acquire the physical appearance of the opposite sex through hormonal or surgical manipulation (2).

More recently, the American Psychiatric Association have published the fifth edition of the Diagnostic and Statistical Manual of Mental Disorders (DSM-5), where the term Gender Identity Disorder was replaced by Gender Dysphoria with the main objective of avoiding stigmatization and ensure clinical care to those who see themselves and feel different from the gender assigned to them. The text also emphasizes that gender nonconformity is not, by itself, a mental disorder (3).

In this paper, we will use the ICD-10 nomenclature, Transsexualism, because it has been the most widely used term.

Didactically, Transsexualism is classified into: 1) Male transsexualism: refers to all $46, \mathrm{XY}$ individuals with normal male phenotype who wishes to live and be accepted as a female; 2) Female transsexualism: refers to all 46, XX individuals with normal female phenotype with desire to live and be accepted as a male.

Transsexualism is extremely rare and there is a variety in reported prevalence rates from 1:11,900 to $1: 45,000$ for male transsexualism, and $1: 30,400$ to $1: 200,000$ for female transsexualism (4).

\section{REGULATION OF THE TRANSSEXUAL PROCESS IN BRAZIL}

The first regulation of medical procedures for transsexual patients occurred 15 years ago with the publication of Resolution $n^{\circ} 1482 / 97$ by the Federal Council of Medicine (FCM), which authorized sex reassignment surgery in patients diagnosed as transsexuals, who were 21 years old or older, at public or university hospitals, after at least 2 years of psychotherapy and after signing an informed written consent form (www.portal.cfm.org.br).
Five years later, the FCM published Resolution $\mathrm{n}^{\circ}$ $1652 / 02$, which revoked and extended the earlier one. It removed the experimental nature of the male to female sex reassignment surgery (feminization), authorizing its execution in any public or private hospitals, which fulfilled the required criteria of the previous resolution. The female to male sex reassignment surgery is still restricted to university hospitals, maintaining its experimental character (www.portal.cfm.org.br).

In 2008, the Brazilian Ministry of Health published SUS/MS Ordinance $n^{\circ} 457 / 2008$, which regulated the Transsexual Process in the Brazilian Public Health System, in accordance with the guidelines determined earlier by the FCM. Four hospitals in the country are named Reference Centers, Hospital de Clínicas at Universidade Federal do Rio Grande do Sul - Porto Alegre/ RS, Hospital Universitário Pedro Ernesto at Universidade Estadual do Rio de Janeiro - Rio de Janeiro/RJ, Hospital das Clínicas at the Medical School of Universidade de São Paulo - São Paulo/SP, Hospital das Clínicas at Universidade Federal de Goiás - Goiânia/GO (5).

Finally in 2010, the FCM, by means of Resolution $\mathrm{n}^{\mathrm{o}} 1955 / 2010$, expanded sex reassignment surgical procedures contained in previous resolutions, authorizing the multi-modality treatment only in institutions that fully contemplated the previously established prerequisites (www.portal.cfm.org.br).

In summary, the sex reassignment procedures necessary for the treatment of transsexual patients are allowed in our country, at Medical Services that have a multidisciplinary team composed of a psychologist, a social worker, a psychiatrist, an endocrinologist and surgeons (gynecologists, plastic surgeons, and urologists). To undergo surgery, transsexual patients must be 2175 years old, being in cross-sex hormone therapy for at least 1 year, and psychotherapy for at least two years.

\section{TRANSSEXUAL PATIENT MANAGEMENT}

Several studies have shown that transgender individuals are at increased risk of committing suicide and selfharm, or experience depression $(6,7)$. Suicide risk was significantly higher among those who had previously attempted suicide, or symptoms of impulsivity, or no family/social support. This data underscore the need to develop reception and treatment programs for this vulnerable population (6).

The process of gender reassignment should be multi- and interdisciplinary, in which the endocrinologist has a key role. 
As proposed by the Harry Benjamin International Association of Gender Dysphoria, the interdisciplinary team should consist of a psychologist, a psychiatrist, an endocrinologist, and a surgeon who should participate in an integrated and consistent way across all the steps of the treatment process of transsexuals (8). The psychologist and the psychiatrist should make the diagnosis of transsexualism and recommend hormonal treatment; the endocrinologist, in his or her turn, would initiate and monitor the cross-sex hormonal treatment and collaborate in the indication of sex reassignment surgery. Finally, the surgeon must be responsible for sex reassignment surgeries required to complete the transsexual process (9).

In the outpatient Developmental Endocrinology Unit of Hospital das Clínicas at the Medical School of Universidade de São Paulo, the self-called transgender patients are evaluated according to the "Protocol for the Evaluation and Treatment of Transgender Patients" developed by the multidisciplinary team.

The evaluation and treatment process of transsexual patients obey the following flow: 1) Initially the patient is submitted to diagnostic evaluation by a psychologist and a psychiatrist by means of interviews and questionnaires that address the diagnostic criteria established by the DSM-4 and ICD-10 (we recommend that patients stop taking cross-sex hormones for at least 1 month before and during the evaluation); 2) Once the diagnosis of transsexualism is established, psychotherapy is initiated; 3) After six months of psychotherapy, the patient is referred to an endocrinologist for cross-sex hormone therapy; 4) After at least two years of psychotherapy and cross-sex hormone use, the patient is referred to surgeons for the sex reassignment surgeries; 5) Finally, the patient is maintained in postoperative psychotherapy for at least 1 year, and followed up indefinitely by the endocrinologist.

Transgender individuals seek to develop desired gender physical characteristics and should be submitted to an effective and safe treatment regimen. The goal of treatment is to rehabilitate the individual as a member of society in the gender that he/she identifies with.

\section{PSYCHOLOGICAL EVALUATION AND PREPARATORY PSYCHOTERAPY FOR SURGERY}

Generally speaking, psychological evaluation for these patients does not significantly differ from the psychological assessment procedures intended for any other population, contemplating the evolution of the individual by means of psychological assessment instruments, such as: freely structured interviews, and patterned psy- chological assessment instruments. For the structured interview we use a specific questionnaire that covers aspects of childhood, adolescence and adulthood, developed of our psychologists.

The proper time for surgery is determined during the psycotherapeutic process based on the relationship between patient and therapist. Besides offering a psychotherapeutic space for elaboration of conflicts and issues regarding gender identity, several variables are taken into account, such as general state of mental health of the patient, ability and style of conflict resolution, quality of interpersonal relationships, ability to deal with frustrations and limitations, particularly in relation to the idealization of esthetic and functional results of surgery. Relatives and/or spouses are invited for interviews for elaboration and guidance regarding the treatment offered.

\section{CROSS-SEX HORMONE THERAPY}

According to American Society of Endocrinology treatment guidelines of transsexual patients, the beginning of hormone therapy must follow well-defined criteria. The patient must: 1) demonstrate knowledge and understanding of the expected and side effects of cross-sex hormone use; 2) complete a real life experience in the desired gender for at least three months, or psychotherapy for a period determined by the psychotherapist to consolidate gender identity and 3 ) be likely to take hormones in a responsible manner $(9)$.

The main objectives of the cross-sex hormone treatment for transsexual patients are: 1) to induce the appearance of sexual characteristics compatible with gender identification; 2) to reduce endogenous hormone levels and, therefore, the secondary sexual characteristics of biological sex; and 3) to establish the ideal dosage of the cross-sex hormones that allows physiological hormone serum levels compatible with the patient's desired gender, adopting the principles of hormone replacement therapy for hypogonadic patients.

We often observe, in our medical practice, the use of pharmacological doses of cross-sex hormones, mainly by male transsexuals who wish to obtain rapid development of breasts and control of facial hair growth. However, high doses of cross-sex hormones are not necessary to achieve the desired effects, and are frequently associated with undesirable side effects.

Hormone therapy provides a strong relief from suffering caused by the inadequacy of the phenotype with the gender identity. 


\section{Female transsexual subjects}

Different therapeutic regimens with different pharmaceutical forms of testosterone have been used in the main Centers for transsexual medical care around the world. Testosterone is the principal agent used to induce male characteristics in these patients. Several testosterone formulations are available, including the short-acting intramuscular injections of testosterone esters, the long-acting testosterone undecanoate for intramuscular injection, testosterone adhesives and gels, subcutaneous systems, buccal adhesive and the oral form of testosterone undecanoate. The oral $17 \alpha$-alkylated form, such as fluoximetazona and methyltestosterone, are modified to decrease the fast hepatic metabolism, conferring to them important hepatotoxicity. Therefore, they are not indicated for androgen therapy.

The most widely preparations used in our country are the short-acting testosterone esters for intramuscular injection because of their low cost. However, they do not mimic the endogenous circadian rhythm of testosterone release, and promote supraphysiological levels during the first days after injection. With this regimen, there is an increase of the frequency of side effects, such as increased libido, aggressiveness and hyper-sweating (10).

The available pharmaceutical forms for androgen replacement therapy with their advantages and disadvantages are summarized in table 1 .

In the outpatients of the Developmental Endocrinology Unit of Hospital das Clínicas at the Medical School of Universidade de São Paulo, we use the shortacting testosterone cypionate for intramuscular injection in a dosage of $200 \mathrm{mg}$ every 15-21 days. Its main advantage over the pharmaceutical form that combines three testosterone esters is that it does not determine a very high testosterone peak in the first days after application. After the induction of the virilization period, if no side effects are observed, we use a $200 \mathrm{mg}$ of testosterone cypionate each 1-2 weeks for 6 months to increase clitoral size, facial hair and muscle mass. After this period, the usual dose of one injection every 14 days is indicated.

Primary therapeutic schemes proposed for the treatment of female transsexuals in the principal centers in the world is shown in table 2 .

Table 1. Available androgens for clinical use

\begin{tabular}{|c|c|c|c|}
\hline Composition & Dose & Advantages & Disadvantages \\
\hline $\begin{array}{l}\text { Propionates }+ \text { isocaproate }+ \\
\text { injectable testosterone decanoate }\end{array}$ & 250 mg/2-3 week & $\begin{array}{l}\text { Low cost } \\
\text { One dose every } 2-3 \text { weeks }\end{array}$ & $\begin{array}{l}\text { Does not mimic the circadian rhythm of testosterone } \\
\text { release } \\
\text { Provides supra-physiological levels of testosterone } \\
\text { within the first days after application }\end{array}$ \\
\hline Testosterone cypionate injection & 200 mg/2-3 week & $\begin{array}{l}\text { Low cost } \\
\text { One dose every } 2-3 \text { weeks }\end{array}$ & $\begin{array}{l}\text { Does not mimic the circadian rhythm of testosterone } \\
\text { release } \\
\text { Leads to supra-physiological levels of testosterone } \\
\text { within the first days after application }\end{array}$ \\
\hline Injectable testosterone undecanoate & $1,000 \mathrm{mg} / 12$ week & $\begin{array}{l}4 \text { injections/year } \\
\text { Does not provides supra-physiological levels of } \\
\text { testosterone }\end{array}$ & High cost \\
\hline Transdermal patch & $5 \mathrm{mg} / \mathrm{d}$ & $\begin{array}{l}\text { Mimics the circadian rhythm of testosterone release } \\
\text { Moderate cost } \\
\text { Leads to physiological levels of testosterone }\end{array}$ & $\begin{array}{l}\text { Not available in Brazil } \\
\text { Daily use } \\
\text { Often causes skin irritation at the application site } \\
\text { High cost }\end{array}$ \\
\hline Transdermal gel & $5 \mathrm{~g} / \mathrm{d}$ & $\begin{array}{l}\text { Quick and efficient absorption } \\
\text { Maintains satisfactory levels of testosterone } \\
\text { Does not cause skin irritation at the application site }\end{array}$ & $\begin{array}{l}\text { Not available in Brazil } \\
\text { Daily use } \\
\text { High cost }\end{array}$ \\
\hline Subcutaneous implants & $\begin{array}{l}600 \mathrm{mg} / 4-6 \\
\text { months }\end{array}$ & $\begin{array}{l}\text { Leads to stable and physiological testosterone levels } \\
\text { One implant every } 6 \text { months }\end{array}$ & $\begin{array}{l}\text { Not available in Brazil } \\
\text { Possibility of extrusion and local infection }\end{array}$ \\
\hline Oral testosterone undecanoate & $80-160 \mathrm{mg} / \mathrm{d}$ & $\begin{array}{l}\text { The only effective and safe oral testosterone ester } \\
\text { Does not cause hepatotoxicity }\end{array}$ & $\begin{array}{l}\text { Daily use } \\
2 \text { to } 4 \text { daily doses }\end{array}$ \\
\hline Oral system & $30 \mathrm{mg} / 12 \mathrm{~h}$ & $\begin{array}{l}\text { Mimics the circadian rhythm } \\
\text { Leads to physiological levels of testosterone } \\
\text { Does not seem to cause mucosal irritation at the } \\
\text { injection site }\end{array}$ & $\begin{array}{l}\text { Not available in Brazil } \\
2 \text { daily doses } \\
\text { High cost } \\
\text { Short experience of clinical use }\end{array}$ \\
\hline
\end{tabular}


Table 2. Proposed regimens for the treatment of female transsexual subjects

\begin{tabular}{|c|c|c|}
\hline Treatment center & $\begin{array}{l}\text { Number of } \\
\text { patients }\end{array}$ & Regimens \\
\hline $\begin{array}{l}\text { Academic Hospital Vrije Univesiteit } \\
\text { Amsterdam, Netherlands }\end{array}$ & 293 & $\begin{array}{l}\text { Testosterone esters } 250 \mathrm{mg} \text { IM every } 2 \text { weeks } \\
\text { Testosterone undecanoate } 160 \mathrm{mg} \text { a day }\end{array}$ \\
\hline $\begin{array}{l}\text { Psychoneuroendocrinology Unit, University of Liége } \\
\text { Liége, Belgium }\end{array}$ & Not reported & $\begin{array}{l}\text { Testosterone } 240 \mathrm{mg} / \mathrm{d} 3 \text { doses } \\
\text { Testosterone esters } 250 \mathrm{mg} \text { IM every 2-4 weeks }\end{array}$ \\
\hline $\begin{array}{l}\text { Division of Endocrinology, Mount Sinai } \\
\text { New York, USA }\end{array}$ & 93 & $\begin{array}{l}\text { Testosterone esters (cypionate or enanthate) 250-400 mg IM every } \\
\text { 2-3 weeks }\end{array}$ \\
\hline $\begin{array}{l}\text { Max-Planck-Institute Endocrinology Clinic } \\
\text { Munich, Germany }\end{array}$ & Not reported & $\begin{array}{l}\text { Testosterone esters } 250 \mathrm{mg} \text { IM every } 2 \text { weeks, reduce in 9-12 m after } \\
\text { desired effect to one dose every } 4 \text { weeks } \\
\text { Optional: progesterone } 500 \mathrm{mg} \text { IM } 2 \text { doses 3-4 days after testosterone }\end{array}$ \\
\hline $\begin{array}{l}\text { Gender Clinic, University of Texas } \\
\text { Texas, USA }\end{array}$ & 30 & Testosterone cypionate $200 \mathrm{mg}$ IM every 2 weeks \\
\hline $\begin{array}{l}\text { Department of Obstetrics and Gynecology, National Universit of Singapore } \\
\text { Singapore }\end{array}$ & 70 & $\begin{array}{l}\text { Testosterone esters } 250 \mathrm{mg} \text { IM every 3-4 weeks } \\
\text { Testosterone cyclopentilpropianate } 100 \mathrm{mg} \text { IM a week }\end{array}$ \\
\hline $\begin{array}{l}\text { Department of Obstetrics and Gynecology, Erlangen University Hospital, } \\
\text { Erlangen, Germany }\end{array}$ & 37 & Testosterone undecanoate $1,000 \mathrm{mg}$ IM every 12 weeks \\
\hline Personal experience & 50 & Testosterone cypionate 200 mg IM every 2-3 weeks \\
\hline
\end{tabular}

Adapted from: Costa and Mendonça (30).

The interruption of menstrual cycles, breast atrophy, voice deepening, increased body hair, clitoris enlargement, libido improvement, redistribution of body fat and increased muscle mass, are the effects expected by female transsexuals under testosterone therapy.

The long-term follow-up (around 10 years) of our 40 patients, demonstrated that all patients into at least one year of treatment showed voice deepening, increased body hair, enlargement of the clitoris $(3.5-5.0 \mathrm{~cm})$, breast atrophy and increased libido. It is important to highlight that the interruption of menses occurs in the first 2-3 doses of short-acting testosterone. At clinical examination an increase in muscle mass occurred in $77 \%$, and fat redistribution in $91 \%$ of the patients.

The administration of testosterone enanthate every two weeks is able to maintain serum testosterone levels within the normal range for young adult men (11). In our cohort, the use of $200 \mathrm{mg}$ of testosterone cypionate biweekly was also able to maintain testosterone levels within the normal range for adult men (normal: 200-950 ng/dL). LH and FSH levels were above the normal range for women in the follicular phase, $6.13 \pm$ $9.4 \mathrm{U} / \mathrm{L}$ and $12.17 \pm 15.2 \mathrm{U} / \mathrm{L}$ respectively, despite normal testosterone levels for male sex, showing that the hypothalamic pituitary ovarian axis is not completely inhibited by exogenous testosterone at physiological doses for males.

Despite the few number of studies that evaluated the effect of testosterone administration in female transse- xuals, most of the effects described above are achieved with the schemes proposed in the literature $(12,13)$.

\section{Side effects of androgen replacement}

It is quite reasonable to accept that the use of testosterone for female transsexual patients may be associated with adverse effects, such as acne, venous thromboembolism, atherosclerosis, weight gain, onset or worsening of sleep apnea, aggressiveness, hyper-sexuality, hypertension, polycythemia, worsening lipid profile, decreased insulin sensitivity, and increased growth factors, as well as increased risk of breast and ovarian cancer (14).

Based on the combined cardiovascular risks derived from testosterone replacement, the evaluation of cardiovascular function in female transexuals patients is recomended (9). However, a recent meta-analysis concluded that the assessment risk of androgen administration in these patients is limited due to the extremely low level of evidence of the studies. They are not controlled and have an observational nature, with small numbers of patients and short follow-up period. In addition, treatment regimens are varied and have inconsistent results (15).

In the group of transgender women followed up in our clinic, we observed that the most frequent side effects of androgen therapy was acne which occurred in $70 \%$ of cases, weight gain in $25 \%$, hyper-sexuality and aggressiveness in $20 \%$ and hypertension in $25 \%$ of them. There was an increase in hematocrit in all patients; however, none reached polycythemic levels. It 
has been demonstrated that polycythemia is associated with supra-physiological levels of testosterone (10). Liver enzymes and bone mass remained unchanged; one patient had endometrial hyperplasia; polycystic ovaries were found in one patient before treatment; and another had dyslipidemia.

Based on our results, we can conclude that the use of intramuscular injection short-acting testosterone enanthate in a dose of $200 \mathrm{mg}$ biweekly was effective and safe for female transsexuals treatment.

\section{Male transsexual subjects}

Estrogen is the chosen hormone to induce female secondary sexual characteristics in these patients.

There is a large number of pharmaceutical estrogen preparations, including oral, injectable, transdermal, and intravaginal forms associated or not with progesterone. The estrogens used in these preparations can be natural (estrone, estradiol, and $17 \alpha 17 \beta$-estradiol), or synthetic (estradiol valerate, estradiol benzoate, and ethinylestradiol).

Oral preparations are the most widely used, due to the higher cost of the transdermal route. However, for male transsexuals over 40 years of age, the transdermal route is recommended due to the lower association of transdermal $17 \beta$-estradiol replacement with thromboembolic events (16). With the preparations for intramuscular injections, the period for the development of secondary sexual characteristics is longer, leading to dissatisfaction and abuse of dosage by patients (17).

The main estrogens currently used for hormone replacement therapy are shown in table 3 .

Anti-androgens are used as adjuvants to estrogen, especially in the reduction of male sexual characteristics and the suppression of testosterone to levels compatible with the female sex. Cyproterone acetate blocks testosterone binding to its receptor, and in a dose of $50-100 \mathrm{mg} /$ day can reduce testosterone levels to fe-

Table 3. Most frequently used estrogens in hormone replacement

\begin{tabular}{lcc}
\hline Estrogen type & Administration route & Replacement dose \\
\hline $17 \beta$ estradiol & Patch & $100-200 \mu \mathrm{gg} / \mathrm{d}$ \\
$17 \beta$ estradiol & Gel & $1.5-2 \mathrm{mg} / \mathrm{d}$ \\
Estradiol cypionate & IM & $3 \mathrm{mg} / \mathrm{m}$ \\
Micronized estradiol & Oral & $2-4 \mathrm{mg} / \mathrm{d}$ \\
Estradiol valerate & Oral & $2-4 \mathrm{mg} / \mathrm{d}$ \\
Conjugated estrogens & Oral & $1.25-2.5 \mathrm{mg} / \mathrm{d}$ \\
Ethinyl estradiol & Oral & $20 \mu \mathrm{g} / \mathrm{d}$ \\
\hline
\end{tabular}

male levels in male transsexual subjects (18). The use of GnRH as an enhancer of estrogenic effects has been suggested especially in those patients in whom risk factors limit the dose of estrogen (19). Some authors defend the association of progestins in the treatment of TM to enhance breast enlargement and decrease the sensitivity of the breast parenchyma. However, this combination increases the risk of coronary heart disease, stroke, thromboembolic events, and breast cancer in postmenopausal women (20). On the other hand, it is important to mention that the characteristics of transsexuals are different from those of menopausal women, as well as the type of estrogen used, with this being an indirect comparison. Furthermore, literature review concluded that cardiovascular outcomes in this population are very rare (15).

Different therapeutic schemes using different pharmaceutical forms of estrogens alone or combined with drugs that potentiate its action have been used in major centers of transsexual treatment in the world (Table 4). Doses higher than those recommended may be used for short period of time in special situations, such as not suppressed testosterone levels and inadequate mammary development.

The 150 male transsexuals followed in our clinic use conjugated equine estrogens at a dose of 0.625 $\mathrm{mg} /$ day associated with cyproterone acetate at a dose of $50 \mathrm{mg}$ /day. In cases of insufficient breast growth, estrogen dose is doubled $(1.25 \mathrm{mg} /$ day $)$ or replaced by more potent estrogens, such as ethinyl estradiol 35 $\mu \mathrm{g} / \mathrm{d}$ for 6 months. If there is no breast growth after this period, we return to the initial dose of estrogen and indicate breast implants.

Enlargement of breasts, nipples and areola, decreased spontaneous erections and decreased body hair are the most desired clinical signs of estrogen replacement. Skin softness, redistribution of body fat, reduction of aggressiveness, and decrease of testicular volume also occurs. These effects should be achieved with the lowest possible dose of medications, in order to prevent adverse side effects.

Currently, the vast majority of patients followed in our clinic use conjugated equine estrogens at a dose of $0.625 \mathrm{mg} /$ day associated with $50 \mathrm{mg} /$ day of cyproterone acetate for an average period of 11 years. All patients reported prior use of others estrogen formulations without medical supervision for a variable period of time. Breast development was satisfactory in most patients, there was a change in skin texture, decrease of sponta- 
Table 4. Proposed regimens for the treatment of female transsexual subjects

\begin{tabular}{|c|c|c|}
\hline Treatment center & $\begin{array}{l}\text { Number of } \\
\text { patients }\end{array}$ & Regimens \\
\hline $\begin{array}{l}\text { Academic Hospital Vrije Univesiteit } \\
\text { Amsterdam, Netherlands }\end{array}$ & 816 & $\begin{array}{l}\text { Ethinyl estradiol: } 100 \mathrm{ug} / \mathrm{d} \\
17 \beta \text { transdermal estradiol: } 100 \mathrm{ug} \text { 2x/week } \\
\text { Cyproterone acetate: } 100 \mathrm{mg} / \mathrm{d}\end{array}$ \\
\hline $\begin{array}{l}\text { Psychoneuroendocrinology Unit } \\
\text { University of Liége } \\
\text { Liége, Belgium }\end{array}$ & Not reported & $\begin{array}{l}\text { Ethinyl estradiol: } 50-100 \mathrm{ug} / \mathrm{d} \\
\text { Conjugated estrogens: } 1.25-2.5 \mathrm{mg} / \mathrm{d} \\
\text { Estradiol benzoate: } 25 \mathrm{mg} / \mathrm{week} \\
\text { Optional: spironolactone: } 100-200 \mathrm{mg} / \mathrm{d} \\
\text { Cyproterone acetate: } 50-100 \mathrm{mg} / \mathrm{d}\end{array}$ \\
\hline $\begin{array}{l}\text { Division of Endocrinology, Mount Sinai } \\
\text { New York, USA }\end{array}$ & Not reported & $\begin{array}{l}\text { Ethinyl estradiol: } 100 \mathrm{ug} / \mathrm{d} \\
\text { Conjugated equine estrogens: } 1.25-2.5 \mathrm{mg} / \mathrm{d} \\
\text { Medroxy-progesterone acetate: } 10 \mathrm{mg} / \mathrm{d} \text { for } 10 \mathrm{~d} / \text { month during the first } \\
6 \text { months } \\
\text { Optional: spironolactone } 100-200 \mathrm{mg} / \mathrm{d} \\
\text { Cyproterone acetate }\end{array}$ \\
\hline $\begin{array}{l}\text { Department of Endocrinology, University of British Columbia, Vancouver, } \\
\text { Canada }\end{array}$ & 50 & $\begin{array}{l}\text { Conjugated estrogens: } 0.625 \mathrm{mg} / \mathrm{d} \text { increase to } 5 \mathrm{mg} / \mathrm{d} \text { for } 3 \text { to } 4 \text { weeks } \\
\text { spironolactone: } 100-200 \mathrm{mg} / \mathrm{d} \text { gradual increase until testosterone } \\
\text { suppression } \\
\text { Medroxy-progesterone: } 10 \mathrm{mg} / \mathrm{d} 2 \text { week/month or continuous, if } \\
\text { necessary }\end{array}$ \\
\hline $\begin{array}{l}\text { Max-Planck-Institute Endocrinology Clinic } \\
\text { Munich, Germany }\end{array}$ & Not reported & $\begin{array}{l}\text { Estradiol: } 80-100 \mathrm{mg} \mathrm{IM} \text { every } 2 \text { weeks } \\
17 \beta \text {-estradiol: } 2-8 \mathrm{mg} / \mathrm{d} \text { after } 1 \text { year } \\
\text { Cyproterone acetate: } 100 \mathrm{mg} / \mathrm{d} \text { for } 6-12 \mathrm{~m} \text { until lower level of } \\
\text { testosterone }\end{array}$ \\
\hline $\begin{array}{l}\text { Department of Obstetrics and Gynecology, Erlangen University Hospital, } \\
\text { Erlangen, Germany }\end{array}$ & 37 & Goserelin acetate: 3-8 mg/4 week. + $6 \mathrm{mg}$ estradiol valerate \\
\hline $\begin{array}{l}\text { Gender Clinic, University of Texas } \\
\text { Texas, USA }\end{array}$ & 60 & $\begin{array}{l}\text { Ethinyl estradiol: } 100 \mathrm{ug} / \mathrm{d} \\
\text { Conjugated equine estrogens: } 7.5-10 \mathrm{mg} / \mathrm{d}\end{array}$ \\
\hline Personal experience & 150 & Conjugated estrogens: 0,625 -1,25 mg/d \\
\hline
\end{tabular}

Adapted from: Costa and Mendonça (30).

neous erections and in the speed of facial and body hair growth, as well as its texture (especially after association with cyproterone acetate) and decreased aggression. The redistribution of body fat has been clinically observed in $97 \%$ of cases and enlargement of the areola and nipple in $50 \%$. Testicular volume was reduced in all cases.

Testosterone levels remained at pre- or intra-pubertal female range $(<14-99 \mathrm{ng} / \mathrm{dL})$ in all patients; $\mathrm{LH}$ levels were pre-pubertal $(<0.6-0.7 \mathrm{U} / \mathrm{L})$ in $72 \%$ of the cases, and the FSH levels were suppressed $(<1.0 \mathrm{U} / \mathrm{L})$ in $40 \%$ of cases. Therefore, daily use of oral conjugated estrogens at low doses in association with cyproterone acetate is effective in suppressing the hypothalamic-pituitary-testicular axis in male transsexuals.

The most disturbing side effect related to estrogen therapy in male transsexuals is venous thromboembolism, particularly during the first year of treatment, when the incidence of this event is $2-6 \%$ falling to $0.4 \%$ in the second year. This incidence is significant when compared with the incidence of this event in the overall young population $(0.005$ to $0.01 \% /$ year $)(21,22)$. This high incidence of thromboembolic events in male transsexuals seems more associated with ethinyl estradiol than natural oral or transdermal estrogens (23).

The risk of venous thromboembolism in patients taking estrogen increases significantly in the presence of smoking, cardiovascular disease, deficiency of thromboembolic factors, particularly the factor $\mathrm{V}$ and anti-thrombin (24). The current recommendation is that the use of ethinyl estradiol should be avoided, and preference should be given to natural or conjugated estrogens, especially in patients over 40 years of age (25).

All patients on estrogen therapy have elevated prolactin levels. Typically, the prolactin increase is mild. However, a small percentage of these patients have galactorrhea and prolactin levels similar to those found in prolactinomas. There are reported cases of male transsexuals patients who developed prolactinomas (26). 
Sosa and cols. observed that chronic administration of estrogen caused a decrease in levels of total cholesterol, LDL cholesterol, and apoprotein B (27). However, a recent meta-analysis concluded that the work is inconsistent and inconclusive regarding the cardiovascular outcomes in these patients (15).

The chronic administration of estrogens in male transsexuals does not seem to affect bone metabolism, and prevents bone loss induced by deprivation of testosterone (28).

The incidence of breast cancer in male transsexuals on estrogen therapy is extremely low, there are only isolated cases reported in the literature (29).

The evaluation of the risks of cross-sex hormone therapy in 150 male transsexual patients followed up at our clinic with an average age of 34 years, and a mean follow-up of 11 years, we observed a low incidence of side effects with the treatment used $(0.625 \mathrm{mg}$ equine estrogen conjugated $+50 \mathrm{mg}$ cyproterone acetate). Depression was the most common side effect in our patients, observed in 10\% of cases, upper limb venous thrombosis occurred in one case, one patient had an acute myocardial infarction, cardiac arrhythmia also occurred in one case and two patients had macroprolactinoma, which totally regressed with treatment with dopamine agonists. Elevated liver enzymes, alteration in lipid profile, bone loss, and breast cancer were not observed in our cohort.

\section{TRANSGENDER PATIENT MONITORING DURING CROSS-SEX HORMONE THERAPY}

Based on 15 years of clinical practice in the hormonal treatment of these patients, we propose the following monitoring of transsexuals into cross-sex hormone therapy.

\section{Female transsexual subjects}

Clinical examination should be realized every six months with evaluation of weight, blood pressure, body hair, deepening of the voice, increasing muscle mass, body fat redistribution, breast atrophy, and enlargement of the clitoris.

Laboratory evaluation should include biannual dosage of LH, FSH, testosterone, estradiol, liver enzymes, complete blood count, lipid profile, and ultrasound evaluation of the pelvis with endometrial echo. The dosage of testosterone should be held the day before the next application of injectable testosterone, allowing the analysis of the lowest value reached in the interval between injections.

Bone densitometry should be conducted annually for bone mass evaluation.

\section{Male transsexual subjects}

Clinical examination should be performed every six months with evaluation of weight, blood pressure, breast enlargement, involution of body hair, body fat redistribution, and testicular atrophy.

Laboratory evaluation should also be conducted every six months with measurement of $\mathrm{LH}, \mathrm{FSH}$, testosterone, estradiol, prolactin, liver enzymes, complete blood count, coagulation factors, and lipid profile.

Bone densitometry and breast ultrasound should be performed annually.

After surgery in patients over 50 years old, the dosage of PSA should be conducted annually.

Disclosure: no potential conflict of interest relevant to this article was reported.

\section{REFERENCES}

1. Classificação Estatística Internacional de Doenças e Problemas Relacionados à Saúde, versão 10 - CID-10 - 2008. Avaiable at: www.datasus.gov.br.

2. American Psychiatric Association. Diagnostic and Statistical Manual of Mental Disorders, 4th edn, Text Revision. Washington, DC: American Psychiatric Association; 2000. p. 576-82.

3. American Psychiatric Association. Diagnostic and Statistical Manual of Mental Disorders, Fifth Edition - DSM-5; 2013.

4. Coleman E, Bockting W, Botzer M, Cohen-Kettenis P, DeCuypere G, Feldman J, et al. Standards of care for the health of transsexual, transgender and gender-nonconforming people, version 7. Int $\mathrm{J}$ Transgenderism. 2012;13:165-232.

5. Diário Oficial $N^{\circ} 160$, de 20 de agosto de 2008, Seção 1, p. 68.

6. Mustanski B, Liu RT. A longitudinal study of predictors of suicide attempts among lesbian, gay, bisexual, and transgender youth. Arch Sex Behav. 2013;42(3):437-48.

7. Liu RT, Mustanski B. Suicidal ideation and self-harm in lesbian, gay, bisexual, and transgender youth. Am J Prev Med. 2012;42(3):221-8.

8. The Harry Benjamin International Gender Dysphoria Association Standards of care of gender identity disorders 6th version. Avaiable at: http://ww.hbigda.org/soc.html. Accessed on: Nov 17, 2002.

9. Hembree WC, Cohen-Kettenis P, Delemarre-van de Waal HA, Gooren LJ, Meyer III WJ, Spack NP, et al. Endocrine treatment of transexual person: an Endocrine Society clinical practice guideline. J Clin Endocrinol Metab. 2009;94(9): 3132-54.

10. Dobs AS, Meikle AW, Arver S, Sanders SW, Caramelli KE, Mazer NA. Pharmacokinetics, efficacy, and safety of a permeationenhanced testosterone transdermal system in comparison with bi-weekly injections of testosterone enanthate for the treatment of hypogonadal men. J Clin Endocrinol Metab. 1999;84:3469-78. 
11. Snyder P, Lawrence D. Treatment of male hypogonadism with testosterone enanthate. J Clin Endocrinol Metabol. 1980;51:1335-9.

12. Elbers J, Asscherman H, Seidell J, Frolich M, Meinders E, Gooren L. Long-term testosterone administration increases visceral fat in female to male transsexual people. J Clin Endocrinol Metab. 1997;82:2044-7.

13. Schlatterer K, von Werder K, Stalla G. Multistep treatment concept of transsexual patients. Exp Clin Endocrinol Diabetes. 1996;104:413-9.

14. Gooren LJ, Giltay EJ. Review of studies of androgen treatment of female-to-male transsexuals: effects and risks of administration of androgens to females. J Sex Med. 2008;5:765-76.

15. Elamin MB, Garcia MZ, Murad MH, Erwin PJ, MontoriVM. Effect of sex steroid use on cardiovascular risk in transsexual individuals: a systematic review and meta-analyses. Clin Endocrinol (Oxf). 2010;72(1):1-10.

16. van Kesteren P, Asscheman H, Megens J, Gooren L. Mortality and morbidity in transsexual subjects treated with cross-sex hormones. Clin Endocrinol (Oxf). 1997;47:337-42.

17. Asscheman $\mathrm{H}$, Gooren L. Hormone treatment in transsexual people. J Psychol Hum Sex. 1992;5:39-54.

18. Jequier A, Bullimore N, Bishop M. Cyproterone acetate and a small dose of oestrogen in the pre-operative management of male transsexual people. A report of three cases. Andrologia. 1989;21:456-61.

19. van Kesteren $P$, Lips $P$, Gooren L, Asscheman H, Megens J. Longterm follow-up of bone mineral density and bone metabolism in transsexual people treated with cross-sex hormones. Clin Endocrinol (Oxf). 1998;48:347-54.

20. Moore E, Wisniewski A, Dobs A. Endocrine treatment of transsexual people: a review of treatment regimens, outcomes and adverse effects. J Clin Endocrinol Metabol. 2003;88:3467-73.
21. Asscheman H, Gooren LJ, Eklund PL. Mortality and morbidity in transsexual patients with cross-gender hormone treatment. Metabolism. 1989;38(9):869-73.

22. van Kesteren $P$, Asscheman $H$, Megens J, Gooren L. Mortality and morbidity in transsexual subjects treated with cross-sex hormones. Clin Endocrinol (Oxf). 1997;47:337-42.

23. Toorians AW, Thomassen MC, Zweegman S, Magdeleyns EJ, Tans G, Gooren LJ, et al. Venous thrombosis and changes of hemostatic variables during cross-sex hormone treatment in transsexual people. J Clin Endocrinol Metab. 2003;88(12):5723-9.

24. Vandenbroucke JP, Koster T, Briet E, Reitsma PH, Bertina RM, Rosendaal FR. Increased risk of venous thrombosis in oralcontraceptive users who are carriers of fator $V$ Leiden mutation. Lancet. 1994;344:1453-7.

25. Gooren LJ. Clinical practice. Care of transsexual persons. N Engl J Med. 2011;364:1251-7.

26. Gooren LJ, Giltay EJ, Bunck MC. Long-term treatment of transsexuals with cross-sex hormones: extensive personal experience. J Clin Endocrinol Metab. 2008;93(1):19-25.

27. Sosa M, Jódar E, Arbelo E, Domínguez C, Saavedra P,Torres A, et al. Serum lipids and estrogen receptor gene polymorphisms in male-to-female transsexuals: effects of estrogen treatment. Eur J Intern Med. 2004;15(4):231-7.

28. Lips $P$, Asscheman H, Uitewaal P, Netelenbos JC, Gooren L. The effect of cross-gender hormonal treatment on bone metabolism in male-to-female transsexuals. J Bone Miner Res. 1989;11:1769-73.

29. Ganly I, Taylor EW. Breast cancer in a trans-sexual man receiving hormone replacement therapy. Br J Surg. 1995;82:341.

30. Costa EMF, Mendonça BB. Terapia hormonal no transexualismo. Cap. 11, p. 111-23. In: VieiraT, Paiva LAS (eds). Identidade sexual e transexualidade. São Paulo: Editora Roca; 2009. 